UCRL-JC-128065

PREPRINT

\title{
APT/LEDA RFQ Vacuum Pumping System
}

\author{
S. Shen \\ K. Kishiyama \\ J. M. Parker \\ N. G. Wilson \\ D. Schrage
}

This paper was prepared for submittal to the

1997 Particle Accelerator Conference

Vancouver, B.C., Canada

May 12-16, 1997

July 21, 1997

This is a preprint of a paper intended for publication in a journal or proceedinga. Since changes may be made before publication, this preprint is made available with the underetending that it will not be cited or reproduced without the permission of the author. 


\section{DISCLAIMER}

This document was prepared as an account of work sponsored by an agency of the United States Government. Neither the United States Government nor the University of California nor any of their employees, makes any warranty, express or implied, or assumes any legal liability or responsibility for the accuracy, completeness, or usefulness of any information, apparatus, product, or process disclosed, or represents that its use would not infringe privately owned rights. Reference herein to any specific commercial product, process, or service by trade name, trademark, manufacturer, or otherwise, does not necessarily constitute or imply its endorsement, recommendation, or favoring by the United States Government or the University of California. The views and opinions of authors expressed herein do not necessarily state or reflect those of the United States Government or the University of California, and shall not be used for advertising or product endorsement purposes. 


\section{S. Shen, K. Kishiyama, J. M. Parker,
Lawrence Livermore National Laboratory, \\ N. G. Wilson, AMPARO, Inc., Santa Fe, NM and
D. Schrage, Los Alamos National Laboratory, Los Alamos, NM}

APT/LEDA RFQ Vacuum Pumping System

\section{Abstract}

This paper describes the design and fabrication of a vacuum pumping system for the APT/LEDA (Low Energy Demonstration Accelerator) RFQ (Radio Frequency Quadrupole) linac [1]. Resulted from the lost proton beam, gas streaming from the LEBT (Low Energy Beam Transport) and out-gassing from the surfaces of the RFQ cavity and vacuum plumbing, the total gas load will be on the order of $7.2 \times 10^{-4}$ Torr-liters/sec, consisting mainly of hydrogen. The system is designed to pump on a continual basis with redundancy to ensure that the minimal "operating vacuum level" of $1 \times 10^{-6}$ Torr is maintained even under abnormal conditions. Details of the design, performance analysis and the preliminary test results of the cryogenic pumps are presented.

\section{INTRODUCTION}

The APTLEDA RFQ consists of four resonantly coupled two meter segments. The over-riding requirement for the APT/LEDA RFQ vacuum pumping system is that it be capable of pumping the combined gas load from the lost proton beam, gas streaming from the LEBT (Low Energy Beam Transport) and out-gassing from the surfaces of the RFQ cavity and vacuum plumbing. The total gas load will be on the order of $7.2 \times 10^{-4}$ Torr-liters/sec. The main gas to be pumped will be hydrogen and the system must be able to pump hydrogen on a continual basis. Vacuum pumps are to be completely oil-free (both highvac and roughing) and a single pump type must pump all other species of gas $\left(\mathrm{O}_{2}, \mathrm{~N}_{2}\right.$ and any outgassed mixture). Redundancy must be provided in the system pumping and gauging to ensure that the minimal "operating vacuum level" of $1 \times 10^{-6}$ Torr is maintained despite pump failures in the system. All pumps, valves and gauges must be replaceable without bringing the RFQ cavity up to atmospheric pressure.

\section{DESIGN}

\subsection{Design Requirements}

Tables 1 and 2 summarize the vacuum parameters and pumping system requirements for the APT/LEDA RFQ respectively.

\begin{tabular}{|c|c|}
\hline PARAMETER & VALUE \\
\hline Surface Outgassing Rate & $\begin{array}{c}2.4 \times 10^{-9} \text { Torr-liters/cm -sec } \\
2.4 \times 10^{-4} \text { Torr-liters/sec }\end{array}$ \\
\hline LEBT Gas Load $\left(\mathrm{H}^{+}\right)$ & $1.1 \times 10^{-4}$ Torr-liters $/ \mathrm{sec}$ \\
\hline $\mathrm{H}^{+}$Beam Loss $(10 \mathrm{~mA})$ & $1.0 \times 10^{-3}$ Torr-liters/sec \\
\hline $\mathrm{H}_{2}^{+} \& \mathrm{H}_{3}^{+}$Injection $(2 \mathrm{~mA})$ & $4.0 \times 10^{-4}$ Torr-liters $/ \mathrm{sec}$ \\
\hline Total $\mathrm{H}_{2}$ Gas Load & $1.4 \times 10^{-3}$ Torr-liters/sec \\
\hline TOTAL GAS LOAD & $7.2 \times 10^{-4}$ Torr-liters $/ \mathrm{sec}$ \\
\hline Pumping Ports & $\begin{array}{l}\text { 366-slots each } \\
140 \text { liters/second each }\end{array}$ \\
\hline Pumping Plenums & $\begin{array}{l}3 @ \text { Section } \mathrm{A1} \\
3 @ \text { Section } \mathrm{A} 2 \\
3 @ \text { Section } \mathrm{C} 2 \\
\end{array}$ \\
\hline
\end{tabular}

Table 1: Vacuum Parameters

\begin{tabular}{|l|l|}
\hline PARAMETER & VALUE \\
\hline Prototype for APT & $\begin{array}{l}\text { System Must be Fully Suitable for } \\
\text { APT Operation }\end{array}$ \\
\hline Operating Pressure & $\leq 1.0 \times 10^{-6}$ Torr \\
\hline System Time Constant & 0.1 second \\
\hline Pump Down Time & $\leq 30$ minutes \\
\hline $\begin{array}{l}\text { Concurrent } \\
\text { Regeneration }\end{array}$ & $\begin{array}{l}\text { Regeneration Must Occur During } \\
\text { Operation }\end{array}$ \\
\hline Installed Redundancy & $\begin{array}{l}\text { System Must Operate with a Pump } \\
\text { Failure During Regeneration }\end{array}$ \\
\hline Redundant Gauging & False Positives Must be Detected \\
\hline Standalone Operation & $\begin{array}{l}\text { System Must Operate Independently of } \\
\text { LEDA Control System }\end{array}$ \\
\hline $\begin{array}{l}\text { Control System } \\
\text { Interface }\end{array}$ & $\begin{array}{l}\text { System Must Accept Commands \& } \\
\text { Provide Signals to LEDA Control } \\
\text { System }\end{array}$ \\
\hline RF Window Vacuum & $\begin{array}{l}\text { System Must Allow for Vacuum } \\
\text { Pumping of 12 RF Windows }\end{array}$ \\
\hline Safety/Codes & $\begin{array}{l}\text { System Must Meet AlICodes \& } \\
\text { Present No Safety Hazards }\end{array}$ \\
\hline
\end{tabular}

Table 2; Pumping System Requirements

\subsection{Design Approach}

Since the intent of the LEDA is that it will be a working prototype for the APT accelerator, it is imperative that the vacuum pumping system for the APT/LEDA RFQ be fully suited for actual APT operation. In developing the conceptual design for the vacuum pumping system we strove to meet the requirements set forth in the scope of work, and also expanded on those requirements by utilizing a "3 R's" approach in the design. We made a conscious effort to build in a robustness that will guarantee adequate pumping during all operating conditions of the accelerator. 


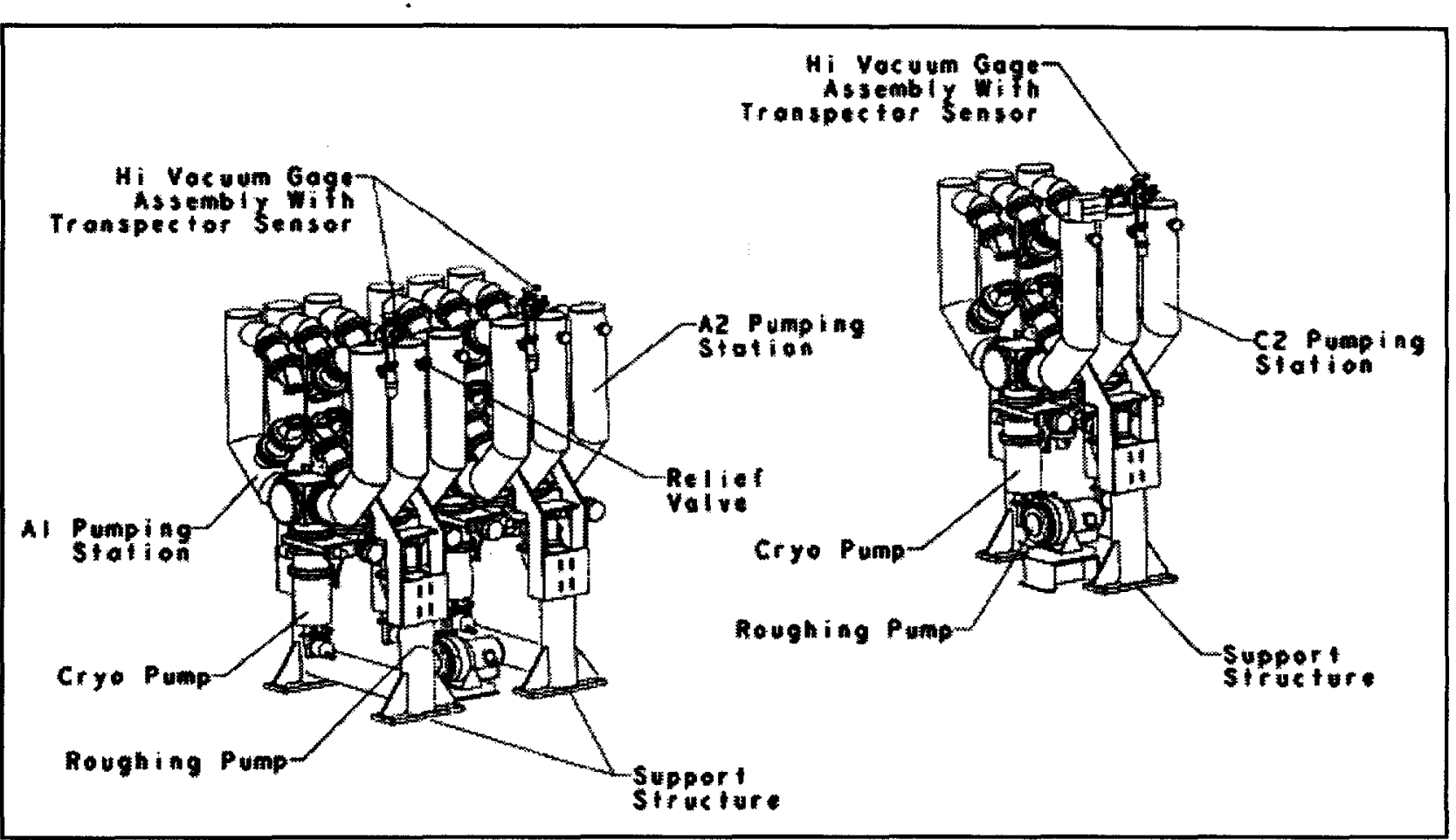

Fig. 1 RFQ Vacuum Pumping System

This was accomplished by researching and specifying reliable components in the system to safeguard against possible failures. In addition, we installed redundancy to counteract any unforeseen operating conditions or vacuum failures in the system.

\subsection{System Design}

Figure 1 shows the layout of the pumping stations and roughing system for sections $A 1, A 2$ and $C 2$ of the RFQ. We opted to use cryopumps based on dynamic analysis of performance during both nominal and abnormal operations, as well as total system pumping speed versus cost. Two Varian DS-600 Dry Scroll Pumps were chosen for the roughing system. These pumps provide a total pumping speed of $1000 \mathrm{~L} / \mathrm{min}$ atatmospheric pressure with an ultimate total pressure of $10^{-2}$ Torr and are totally hydro-carbon free as required. The system can be pumped down to below the cross-over pressure

$(\sim 100 \mathrm{mTorr})$ of the cryopumps in such an arrangement within 30 minutes.

The majority of the pumping is located in sections $\mathrm{A} 1$ and $\mathrm{A} 2$ of the RFQ as most of the gas load occurs in the first two meters. Two $2200 \mathrm{~L} / \mathrm{s}$ (for hydrogen) cryopumps are attached to the pumpstation at section $\mathrm{A} 1$, while section A2 has one $2200 \mathrm{~L} / \mathrm{s}$ cryopump and a 500 $\mathrm{L} / \mathrm{min}$ roughing pump. The vacuum headers of $\mathrm{A} 1$ and $\mathrm{A} 2$ are plumbed together via an 8" spool to allow crosspumping between the two stations. The pumpstation at segment $\mathrm{C} 2$ of the RFQ is similar in configuration to that of $\mathrm{A} 1$ and $\mathrm{A} 2$, but contains two $2200 \mathrm{~L} / \mathrm{s}$ cryopumps and one $500 \mathrm{~L} / \mathrm{min}$ roughing pump.
Having a total of five cryopumps and two roughing pumps in the vacuum system guarantees the ability to individually regenerate cryopumps during accelerator operation. In addition, as shown in the analysis summary, the redundancy ensures that the "operating pressure" is maintained should one pump fail while another is in its regeneration cycle.

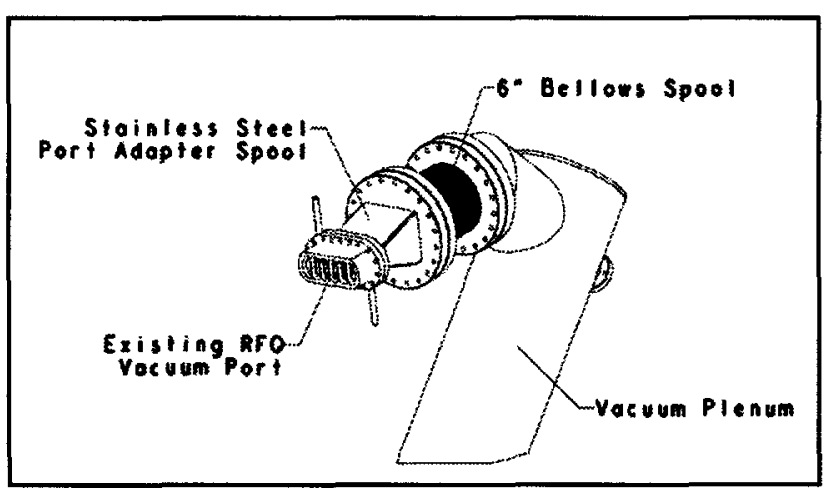

Fig. 2 RFQ Vacuum Port Adaptor Spool \& Bellows Assembly

The port adapter spool shown in figure 2 is constructed from 304 stainless steel plate and an 8" conflat flange. It provides the transition from the RFQ vacuum port to the plenum. The 6 slot configuration of the RFQ vacuum port flange has the poorest conductance of any component in the system and the aggressive taper from the oval shape of the vacuum port flange to the circular plenum flange has a significantly higher conductance than would a straight oval or rectangular 
spool transition piece. Since the RFQ cavities are fabricated from copper, it is difficult to provide a metal seal between the adapter spool and vacuum port. An oring groove, designed to accept a standard sized o-ring, is machined into the mating face of the adapter spool and a viton o-ring will provide the seal. This is the only connection in the high-vac system that will not have a metal seal. However, the RFQ vacuum port is water cooled to a temperature suitable for viton use.

\section{SYSTEM ANALYSIS}

Dynamic system analysis were carried out for pumpdown, nominal operation and under abnormal conditions. This was done by solving the coupled differential Heat-Load Equations described for each segment:

$$
-V_{i} \frac{d P_{i}}{d t}=-Q_{i}+C\left(P_{i}-P_{j}\right)+K\left(2 P_{i}-P_{i+1}-P_{i-1}\right)
$$

where $V_{i}, Q_{i}$ and $P_{i}$ represents the volume, gas load and pressure in segment $i$ respectively. $C$ is the total effective conductance of the RFQ pump ports, and $K$ is the conductance of the coupling plates between two segments. $P_{j}$ is the effective pressure at the port adaptor described by the equation for pump station $j$ as:

$$
-V_{j} \frac{d P}{d t}=S_{j} P_{j}-Q_{j}+C\left(P_{i}-P_{j}\right)
$$

where $S_{j}$ is the effective pump speed at the pump ports with all the conductance of the plumbing taken into account. One example of the analysis results is shown in Fig. 3. Description of the sequence of events is listed in Table 3.

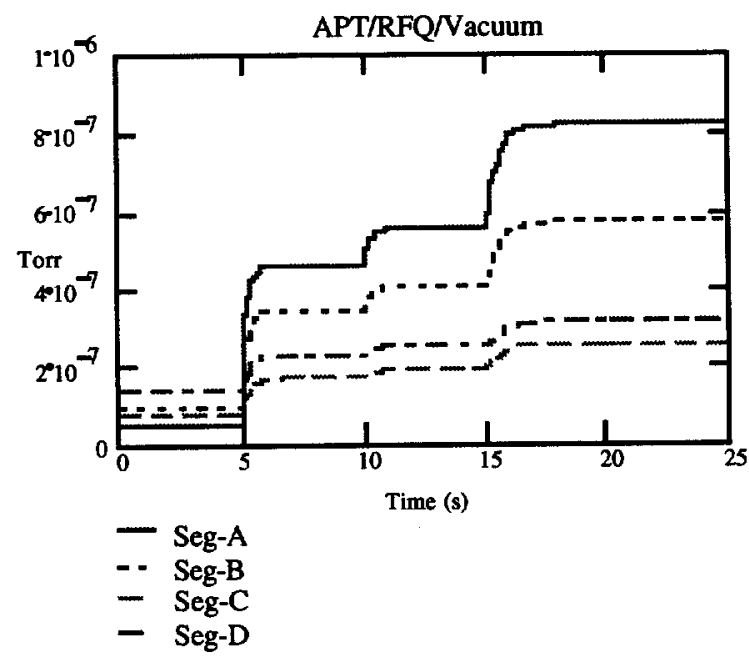

Fig. 3 Analysis Results of Simulation of Loss of Pumps in Segment A.

\begin{tabular}{||c|l|}
\hline Time Interval (s) & Description \\
\hline $0-5$ & Base pressure with out-gassing load \\
\hline $5-10$ & With gas streaming from LEBT \\
\hline $10-15$ & With one pump out of service \\
\hline $15-25$ & With two pumps out of service \\
\hline
\end{tabular}

Table 3 Description Sequence of Events in Fig. 3

It is clearly shown that the minimum operating pressure of $10^{-6}$ Torr can be maintained even if two out of three pumps were taken out of service.

\section{CRYOPUMP TEST}

To verify the major design parameters, we have started a series of performance tests on the cryopumps procured for the system (Ebara ICP 200Q). Major tests include the measurements of $\mathrm{H}_{2}$ pumping speed and $\mathrm{H}_{2}$ capacity. We have adopted the standard test arrangement (AVS Procedure 4.1) [2]. Preliminary results of measured hydrogen pump speed are shown in Fig. 4. It should be notd that the measured value of $2700 \mathrm{~L} / \mathrm{s}$ exceeds the vendor's specified value of $2200 \mathrm{~L} / \mathrm{s}$. Results of the pump speeds with $\mathrm{H}_{2}$ quantity sorbed up to $30 \mathrm{~L}$ will be published at a later date.

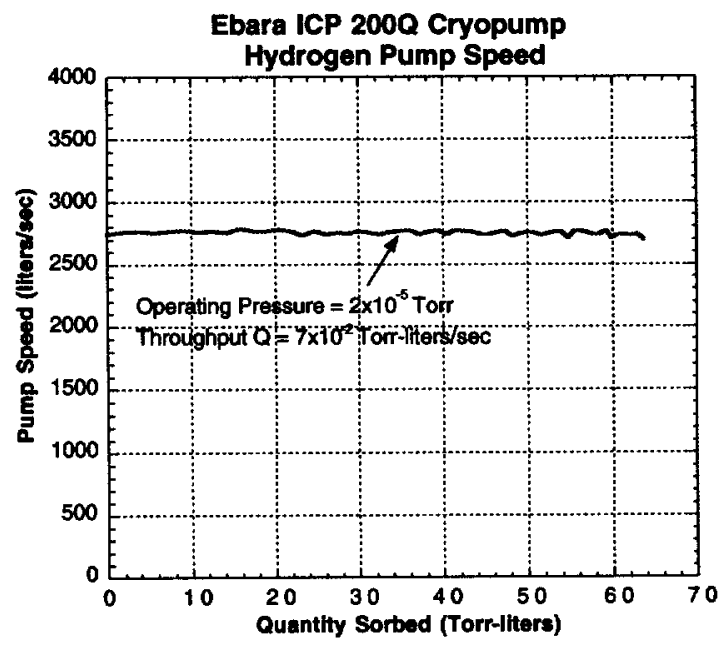

Fig. 4 Measured Pump Speed vs $\mathrm{H}_{2}$ Quantity Sorbed

\section{ACKNOWLEDGEMENTS}

This work was performed under the auspices of the U.S. Department of Energy by Lawrence Livermore National Laboratory under Contract W-7405-Eng-48.

\section{REFERENCES}

[1] D. Schrage: 'A 6.7 Mev CW RFQ Linac,' ibid., (2W.25)

[2] M.H. Hablanian: 'Recommended Procedure for Measuring Pumping Speed,' J. Vac. Sci. Technol. A5(4), July/Aug 1987, 2552 


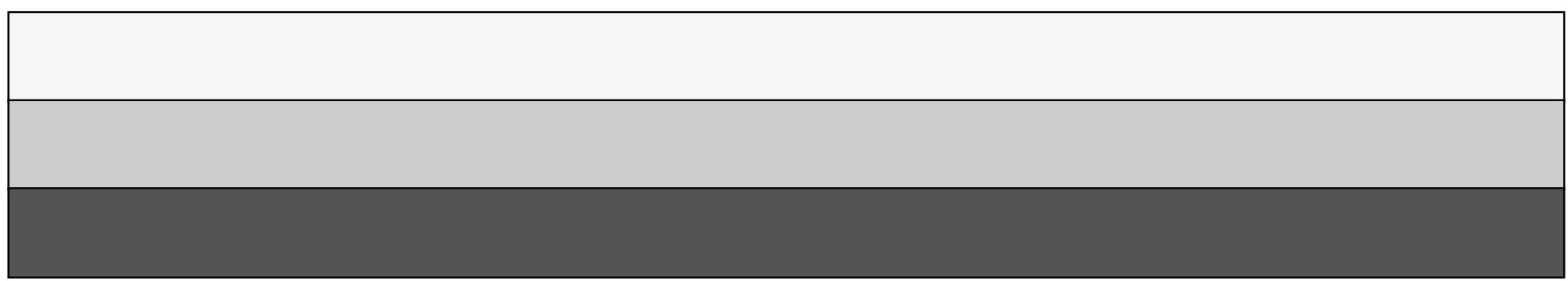

